\title{
A COMPETÊNCIA LEGISLATIVA EM MATÉRIA AMBIENTAL E O PRINCÍPIO DA PROPORCIONALIDADE
}

\author{
http://dx.doi.org/10.21527/2176-6622.2018.50.183-193
}

Recebido em: 19/6/2018

Aceito em: 23/10/2018

\section{Beatriz Souza Costa}

Doutora e mestre em Direito Constitucional pela UFMG. Professora na Pós-Graduação em Direito Ambiental e Desenvolvimento Sustentável da Escola Superior Dom Helder Câmara. biaambiental@yahoo.com.br

Ivan Dutra Doehler

Advogado, especialista em Direito Público pela PUC-MG. Mestrando em Direito Ambiental e Desenvolvimento Sustentável da Escola Superior Dom Helder Câmara. ivandoehler@hotmail.com

\section{RESUMO}

O objetivo do presente artigo é identificar os limites da competência legislativa do município em matéria ambiental, mediante a análise de uma decisão do STF que trata da exigência de complementação de estudos de impacto ambiental, por parte do município, como condição para a expedição de Certidão de Conformidade Ambiental. Tomando-se por base a teoria de Dworkin sobre o direito como integridade, bem como o princípio da proporcionalidade e o da ecoproporcionalidade, questiona-se a interpretação dos limites do interesse local na concessão do licenciamento ambiental e o ativismo judicial. Para tanto, utilizar-se-á o método hipotético-dedutivo baseado na pesquisa explicativa e qualitativa, com base na revisão bibliográfica, na legislação e na jurisprudência pátrias.

Palavras-chave: Competência legislativa do município no licenciamento ambiental. Hermenêutica. Princípio da proporcionalidade.

\section{LEGISLATIVE COMPETENCE IN ENVIRONMENTAL MATTERS AND THE PRINCIPLE OF PROPORTIONALITY}

\section{ABSTRACT}

The objective of this article is to identify the limits of the municipal legislative competence in environmental matters, by analyzing a decision of the STF that deals with the requirement of complementation of studies of environmental impact, by the municipality, as a condition for the issuance of Certificate of Environmental Compliance. Based on Dworkin's theory of law as integrity, as well as the principle of proportionality and that of ecoproportionality, we question the interpretation of the limits of local interest in the granting of environmental licensing and judicial activism. To do so, the hypothetical-deductive method based on explanatory and qualitative research will be used, based on the bibliographical review, the country legislation and jurisprudence.

Keywords: Legislative competence of the municipality in environmental licensing. Hermeneutics. Principle of proportionality.

\section{SUMÁRIO}

1 Introdução. 2 Autonomia, competência administrativa e competência legislativa no plano ambiental. 2.1 o peculiar interesse local e os conflitos de competência. $3 \mathrm{~A}$ empresa e o bem ambiental no constitucionalismo atual. 4 Proporcionalidade e ecoproporcionalidade. 5 A hermenêutica das decisões. 6 Considerações finais. 7 Referências 


\section{INTRODUÇÃO}

O direito ao meio ambiente ecologicamente equilibrado eleva-se, em nosso ordenamento jurídico, à condição de direito humano fundamental, de modo que eventual violação desse direito difuso enseja a intervenção do Poder Judiciário, encarregado de estabelecer os limites da legalidade dos atos administrativos emanados dos entes da Federação. Por se tratar de direitos transindividuais que se encontram envolvidos nas circunstâncias fáticas em que surgem os conflitos de competência legislativa ambiental, devem ser sopesados os interesses dos empreendedores potencialmente poluidores com o direito difuso ao meio ambiente ecologicamente equilibrado, estampado no artigo 225 da Constituição da República de 1988.

Essa intervenção, contudo, deve respeitar limites bem claramente definidos, quando da aplicação da norma ao caso concreto, de modo a evitar-se o ativismo judicial em decisões judiciais proferidas em casos difíceis, configurados na zona cinzenta normativa em que se fundem o interesse local e a ameaça ao equilíbrio ambiental, a ser iluminada pela função judicante. Assim, é de ser questionar até que ponto a hermenêutica constitucional, levada a efeito pelo Supremo Tribunal Federal, significa assumir uma postura legiferante inadmissível no regime democrático, e em que medida a Corte se vale da hermenêutica emergente apta a enfrentar a questão socioambiental no campo normativo e principiológico sem esse viés de interferência, dada a transversalidade do campo dos direitos humanos de quarta dimensão, entre os quais se encontra o direito ao meio ambiente ecologicamente equilibrado.

Por outro lado, o interesse local, como critério de delimitação de competências em matéria de legislação ambiental, reveste-se de nova roupagem ante a natureza difusa dos interesses socioambientais. Essa circunstância exige uma nova atitude diante dos conflitos de competência legislativa no plano do licenciamento ambiental para considerar mais e mais esse elemento local do exercício da cidadania, até mesmo sob a inspiração do princípio da participação popular como corolário do meio ambiente equilibrado enquanto direito humano fundamental.

Nesse contexto, é interessante a apreciação da decisão proferida pela presidente do Supremo Tribunal Federal na Medida Cautelar na Suspensão de Tutela Antecipada 858 - MG, que acatou o pedido do Município de Santa Bárbara, Minas Gerais, e tornou sem efeito a tutela antecipada concedida pelo Desembargador Relator do Tribunal de Justiça de Minas Gerais no Agravo de Instrumento n. 0317791-76.2017.8.13.0000, consistente na determinação da emissão da Certidão de Conformidade Ambiental para fins de licenciamento ambiental "independentemente de qualquer análise técnica ou solicitação de dados ou estudos complementares".

Para amparar a análise da questão jurídico-filosófica da interpretação das normas constitucionais, toma-se de empréstimo a doutrina de Ronald Dworkin como fio condutor da investigação a ser desenvolvida, além do auxílio valioso do arcabouço doutrinário da ecoproporcionalidade de Gerd Winter tomado como critério contemporâneo de solução de conflitos ambientais, tudo à luz do princípio da precaução numa sociedade de risco.

À primeira vista - mesmo sem acesso a informações mais detalhadas, por se tratar de decisão prolatada em sede de cognição sumária, sem abordagem do mérito, em que se discute meramente o periculum in mora decorrente da continuidade de um empreendimento de mineração na área onde recentemente se deu o desastre do rompimento da barragem de rejeitos de Fundão, em Mariana, Minas Gerais - seria de se acreditar que uma indulgência decisória para além do direito positivado aplacaria o clamor popular que mobiliza o imaginário popular num movimento semelhante ao de se colocar cadeado no portão arrombado, na esteira do desastre de Mariana.

Uma decisão judicial, contudo, não se pode prestar a esse papel coadjuvante de levar a efeito a concretização de políticas públicas a cargo do Executivo e nem de preencher lacunas na lei para além da equidade, avançando sobre a seara do Legislativo. Isso se dá por imperativo democrático da divisão republicana de poderes entre os Entes Federativos. O que, portanto, se prescreve atualmente, sob a égide da nova dimensão dos direitos humanos, é a prevalência dos princípios fundadores do sistema normativo consolidados na Constituição como ferramenta essencial na interpretação da norma fundamental da repartição 
federativa da competência legislativa, de modo a incluir a integração do ser humano com a natureza como elemento fundamental do sistema de direitos constitucionais. É isso que importa averiguar nos limites estreitos deste artigo.

\section{AUTONOMIA, COMPETÊNCIA ADMINISTRATIVA E COMPETÊNCIA EGISLATIVA NO PLANO AMBIENTAL}

O município, no ordenamento jurídico brasileiro, é um ente peculiar. Os principais constitucionalistas, como José Afonso da Silva, não admitem o status de Ente Federativo atribuído aos municípios, que ele vê como meras "divisões político-administrativas dos Estados, não da União", de modo que se torna impossível supor a existência de uma "federação de municípios". O resultado dessa incongruência e dubiedade na repartição concorrente é a superposição de entidades e de competências (SILVA, 2013), o que resulta em conflitos de competência no campo legislativo.

José Nilo de Castro ressalta a pertinência do tema da competência do município ao aspecto da autonomia administrativa e vê com restrição a capacidade do município de legislar sobre matéria de interesse local, que, no seu entendimento, era mais ampla quando o texto constitucional referia-se ao "peculiar interesse" como critério de competência na vigência da Constituição anterior (CASTRO, 2006, p. 199).

A competência do município para registrar, acompanhar e fiscalizar as concessões de direitos de pesquisa e exploração de recursos hídricos e minerais em seu território, que é competência concorrente com os Estados e a União, nos termos do inciso XI do artigo 23 da Constituição da República, é de natureza administrativa e faz parte do conjunto de competências derivadas da autonomia concedida aos entes municipais pela Constituição da República. Percebe-se, portanto, que a mens legis do dispositivo constitucional, voltado para a definição do que seja interesse local, reside na atribuição de competência concorrente.

A competência legislativa prevista no inciso I do artigo 30 da Constituição de 1988, que é exclusiva, diz respeito ao aspecto supletivo desse poder de legislar, de modo a não se poder dar interpretação elástica da definição constitucional para abrigar elementos já supridos pela existência de norma federal ou estadual que regulamenta a matéria. Não é possível, por exemplo, que o município exija do empreendimento licenciado por órgão ambiental estadual ou federal, como condição para a emissão da Certidão de Conformidade Ambiental, a apresentação de condicionantes que já fazem parte do acervo de exigências no âmbito do Estudo de Impacto Ambiental ou do Relatório de Impacto Ambiental, sob pena de usurpação da competência de tais órgãos ambientais. Há também, ainda, o aspecto de complementação da legislação estadual ou federal parcialmente omisso, de modo que "o termo suplementar pressupõe o principal o anterior passando a ser adicional, qualificativo da norma resultante da competência" (CASTRO, 2006).

\subsection{0 peculiar interesse local e os conflitos de competência}

A forma pela qual se repartem as competências na Constituição da República de 1988 enseja o surgimento de focos de conflito de competência, seja no plano administrativo, seja no plano legislativo. Se tomada a expressão "interesse local" no seu sentido lato, qualquer assunto que interferisse direta ou indiretamente na vida dos cidadãos poderia ser assim considerado, do mesmo modo que, no sentido inverso, a maioria esmagadora dos interesses defendidos pelas competências estadual e federal são também de interesse local. A expressão, portanto, deve ser temperada cum grano salis e tomada no contexto da repartição das competências, em seu aspecto hierárquico e excludente quando se trata de matérias de competência exclusiva do ente federal, bem como em seu aspecto de suplementação das eventuais lacunas legislativas a cargo da União e dos Estados.

Isso leva a uma "indefinição dos controles", que "com frequência se transforma em controle inexistente, em over regulation" (ANTUNES, 2015). De acordo com o autor, ainda,

se olharmos a indefinição de competências sob a ótica do Estado, veremos que há uma repetição de esforços, com órgãos atuando de forma superposta, com intensa competição interadministrativa, duplicidade de gastos e resultados pouco efetivos para a proteção do meio ambiente. Na verdade, o vigente modelo só atende 
aos interesses de corporações administrativas que resistem heroicamente a terem suas competências mais explicitadas e reduzidas, quando isso redundar em maior eficiência administrativa, hoje princípio constitucional (p. 67).

Se tudo, praticamente, pode ser considerado de interesse local, no campo ambiental essa exacerbação da competência para proteger o meio ambiente e combater a poluição em qualquer de suas formas, nos termos do inciso VI do artigo 23 da Constituição da República, pode levar ao que se denomina de ubiquidade ambiental, de modo que essa atribuição de competência no âmbito da Administração Pública, em seus três níveis, que é de natureza administrativa, fiscalizatória, pode transformar-se, num passe de mágica interpretativa, em competência legislativa redundante e usurpadora da competência de outrem. Desse modo, por mimetismo legislativo, podem multiplicar-se diplomas legais na esfera dos municípios que trazem em seu bojo o germe desse conflito de competências, o que não raro resulta na judicialização do tema.

\section{A EMPRESA E O BEM AMBIENTAL NO CONSTITUCIONALISMO ATUAL}

A ordem econômica encontra-se delineada no artigo 170 da Constituição da República, com fundamento no trabalho e na livre-iniciativa, destinada a assegurar a dignidade da existência sob os ditames da justiça social.

Os princípios insculpidos em seus incisos trazem no mesmo plano axiológico a liberdade de empreender e a garantia da defesa do meio ambiente ecologicamente equilibrado, de modo que se torna redundante a expressão "desenvolvimento sustentável", posto que, por força constitucional, a empresa deve cumprir sua função social e, por que não, sua função socioambiental e, portanto, será necessariamente sustentável o desenvolvimento fundado em tais premissas.

A relação da empresa com o meio ambiente não pode mais pautar-se pela exploração exauriente dos recursos naturais, quase todos tidos até pouco tempo como inesgotáveis, e nem manter os métodos produtivos que dependam da transferência dos passivos ambientais para a sociedade, sob a forma de externalidades representadas pelos custos econômicos, sociais e ambientais que ficam fora dos cálculos da lucratividade do negócio.

Graças à disseminação dos princípios fundamentais de proteção aos direitos ambientais oriundos da Conferência de Estocolmo, em 1972, sobre as constituições econômicas dos países ocidentais e, em particular, sobre a Constituição de 1988, teve início um fluxo legislativo, por assim dizer, que nasce dos princípios retores do meio ambiente ecologicamente equilibrado, e se dissemina em direção à base da pirâmide normativa, de modo a permear todo o sistema normativo.

Costa, Reis e Oliveira (2016) tratam de uma "identidade constitucional ambiental" que se origina de um amálgama de elementos culturais, étnicos, sociais, econômicos, etc., e que tem como expressão de sua existência a presença, no texto constitucional, do "bem ambiental", entendido como o bem de uso comum do povo, definido no caput do artigo 225 da Constituição da República.

É evidente, nesse contexto, que a empresa, como núcleo de produção de bens e serviços, deve observar seu papel nessa rede de proteção ambiental constituída pelos deveres comuns ao Estado e à sociedade, seja por meio do cumprimento de exigências relacionadas ao licenciamento ambiental em atividades de reconhecido impacto ambiental, seja imprimindo à sua prática compromissos de preservação em homenagem aos princípios da prevenção e da precaução, fundados na solidariedade intergeracional.

O bem ambiental tem natureza difusa. No ordenamento jurídico brasileiro, a definição do que seja interesse ou direito difuso provém do Código de Defesa do Consumidor, que estabelece, também, a legitimação da coletividade para sua defesa. Os direitos difusos, segundo o disposto no artigo 81 do CDC, são aqueles direitos transindividuais, de natureza indivisível, de que sejam titulares pessoas indeterminadas e ligadas por circunstâncias de fato. A natureza jurídica difusa do bem ambiental é correlata à transindividualização dos direitos ambientais. Em outras palavras, dar primazia ao direito difuso ao meio ambiente, equilibrado em contraposição ao direito subjetivo individual, equivale a tornar tênues as linhas que separam sujeito e objeto.

Não se pode concordar, nesse sentido, com a afirmativa de que o bem ambiental - entidade imaterial e abstrata - seja considerado bem público de uso comum do povo, na acepção que lhe atribui o artigo 99, inciso I, do Código Civil Brasileiro, malgrado a opinião em sentido contrário de vários autores que tratam da matéria. 
Percebe-se que, nessa visão, os recursos naturais não constituem res nullius, mas res comunis. Essa titularidade indeterminada do bem ambiental, decorrente de sua natureza difusa, é a pedra de toque de uma nova abordagem na exploração dos recursos naturais que entram nos processos produtivos das empresas como insumo e matéria-prima.

O uso irracional dos recursos naturais, preso ao velho paradigma individualista que separa sujeito de objeto pode, malgrado a influência remanescente da filosofia da consciência na ética empresarial, transmutar-se em um emprego racional de recursos que são de todos, indistintamente, num ambiente de que todos e cada um fazem parte, com a fusão no "sujeito ambiental" das dicotomias do velho pensamento alienante e reificador da natureza, tomada como algo separado do ser humano.

É bem verdade que o direito ao meio ambiente equilibrado constitui direito fundamental e que, obviamente, persiste o direito individual subjetivo de pleiteá-lo seja em que aspecto for, mas é de suma importância a legitimação do Ministério Público, nos termos do inciso III do artigo 129 da Constituição, tendo-se em vista a hipossuficiência dos cidadãos que são afetados pelos impactos ambientais de modo difuso.

De acordo com Beatriz Souza Costa, "o bem ambiental está diretamente ligado a sua natureza jurídica. Conforme a Constituição da República Federativa Brasileira, ela é difusa. Sendo assim, esse bem não integra o patrimônio público, mas é patrimônio difuso de 'todos'" (2013, p. 71), acrescentando que, por esse motivo, deve ser preservado pelo Poder Público e pelos cidadãos, incluindo-se, evidentemente, os empresários.

Nesse contexto, é de se esperar que a prática empresarial seja exercida de modo a evitar ao máximo os impactos ambientais, com a aplicação dos princípios da prevenção e da precaução. O que se observa, contudo, é que não há apreço, por boa parte dos empreendedores, à solidariedade com as gerações presentes e futuras.

As normas ambientais são violadas sempre num cálculo de relação custo/benefício que exclui o custo dos danos ambientais, que são socializados, atingindo um número indeterminado de pessoas.

Resta ao Poder Judiciário decidir sobre as questões não raramente judicializadas em decorrência da inobservância das exigências mínimas de conservação do equilíbrio ecológico em seu processo produtivo. O ilícito ambiental tem uma dimensão mais ampla e de potencial mais destrutivo do que delitos de outra natureza, por causa de seu efeito difuso sobre a sociedade.

A hermenêutica apta a reconduzir ao equilíbrio restaurativo do meio ambiente, portanto, é aquela voltada para uma visão unitária e imaterial do bem ambiental. Não se trata de assegurar a mera existência das pessoas, mas de garantir qualidade de vida, pois a hermenêutica emergente deve pautar-se na aplicação da lei ao caso concreto e na compreensão do "meio ambiente essencial à qualidade de vida como o direito à própria vida, mas vida com dignidade, como dispõe a Constituição da República" (COSTA, 2013, p. 78).

A atuação estatal, por meio do Poder Judiciário, na apreciação do caso concreto, em garantia à realização do direito subjetivo universal constitucionalmente garantido ao meio ambiente ecologicamente equilibrado, deve ter por fundamento, em última análise, a dignidade da pessoa humana, sem mencionar as espécie que ele já fez desaparecer definitivamente em consequência da exploração irracional.

Às empresas e aos seus gestores cabe adotar uma "ética da responsabilidade", que parte de uma solidariedade orgânica e intergeracional. A postura do empreendedor diante das fragilidades tem papel determinante na preservação do meio ambiente. A busca pela mitigação dos impactos ambientais tem de ser amparada pela assunção de responsabilidade socioambiental, de forma a se alcançar a melhor solução possível no contexto de licenciamento e operação de um projeto.

Os tempos atuais exigem que na criação de um projeto industrial o empreendedor - como integrante da sociedade - deve pautar-se pela apresentação de um objetivo justificável de ação, adequação, necessidade e sopesamento de meios, de forma a conduzir a decisão no sentido de se escolher entre as alternativas possíveis aquela de menor impacto tanto para a sociedade quanto para a natureza. É o que Gerd Winter (2013, p. 56) denomina "ecoproporcionalidade", como se verá adiante. 


\section{PROPORCIONALIDADE E ECOPROPORCIONALIDADE}

A definição clássica da doutrina constitucionalista do princípio da proporcionalidade é elucidada por Paulo Bonavides em seu sentido lato, como regra que deve ser obedecida por todos os que exercem e todos os que se submetem ao poder, e em seu sentido estrito, no qual se presume a adequação entre os meios e os fins de determinado ato (BONAVIDES, 2003). Ao discorrer sobre a importância do princípio da proporcionalidade para o constitucionalismo contemporâneo, esse autor afirma que

a vinculação do princípio da proporcionalidade ao Direito Constitucional ocorre por via dos direitos fundamentais. É aí que ele ganha extrema importância e aufere um prestígio e difusão tão larga quanto outros princípios cardeais e afins, nomeadamente o princípio da igualdade. Protegendo, pois, a liberdade, ou seja, amparando os direitos fundamentais, o princípio da proporcionalidade entende principalmente, como disse Zimmerli, com o problema da limitação do poder legítimo, devendo fornecer o critério das limitações à liberdade individual (p. 395).

É nessa perspectiva que se coloca a questão da independência dos poderes quando há o controle de legalidade dos atos administrativos, esse espaço estreito reservado ao Poder Judiciário na aplicação da lei emanada do Legislativo, tendo-se em vista que "a substância da criação da lei pelo legislador não pode ser removido por obra de um tribunal", o que significaria "uma passagem para o Estado-Juiz". Por essa razão, o tribunal constitucional deve ater-se, no controle da legalidade e da constitucionalidade das leis, dentro dos limites que a própria Constituição estabeleceu (BONAVIDES, 2003, p. 241).

No aspecto ambiental, contudo, a evolução do princípio da proporcionalidade traz inovações capazes de dar novo tratamento às questões relativas à competência dos entes federativos e novo relevo aos direitos fundamentais. Dentre esses direitos, destaca-se o direito difuso ao meio ambiente ecologicamente equilibrado, como base para se erigir um novo paradigma hermenêutico, que deixa de valorizar o antigo privilégio dos direitos individuais em prol do interesse difuso, coletivo.

A supremacia do interesse difuso ambiental sobre os interesses individuais privados tem boas chances de ser bem-sucedida, de modo a superar a conflituosidade interna característica do direito difuso ambiental, com o emprego da ecoproporcionalidade.

De acordo com Gerd Winter (2013, p. 57), o princípio da proporcionalidade "foi desenvolvido para estruturar as relações de poder entre o poder governamental e os cidadãos", tendo-se originado, na Alemanha, do poder da polícia para garantir a ordem pública, exercido de forma a não interferir de modo exagerado e desnecessário nos interesses individuais, ou, em outras palavras, evitando-se a solução desproporcional ao problema. O princípio da proporcionalidade desenvolveu-se a ponto de tornar-se princípio constitucional de controle do Legislativo, nos casos em que se legisla sobre direitos básicos.

Afirma o autor supracitado que

o Tribunal de Justiça da União Européia (TJUE) adotou o Princípio da Proporcionalidade em sua jurisprudência em matéria de direitos fundamentais europeus como meio de restringir intrusões por parte de autoridades européias. Num segundo momento, o princípio foi aplicado para restringir, em sede de controle europeu, intrusões sobre liberdades básicas européias também por parte dos Estados-Membros. Assim, a proporcionalidade tornou-se um princípio abrangente de domesticação dos poderes governamentais quando interferem em direitos individuais ou no domínio de competência de esferas de governança inferior (p. 59).

A ecoproporcionalidade, proposta pelo pesquisador alemão, é uma analogia segundo a qual a proporcionalidade deve ser não apenas um princípio destinado a regular as relações governamentais para com os cidadãos, mas também ser empregada para as atividades da sociedade que tragam impactos ao meio ambiente, divisando em ambas o denominador comum da limitação do poder (WINTER, 2013).

Prossegue o autor:

A fim de aclarar a terminologia, sugiro nomear os dois tipos de proporcionalidade: "sócio-lógica" e "eco-lógica". Enquanto a proporcionalidade sócio-lógica (ou, em síntese, socioproporcionalidade) deve proteger essencialmente os direitos básicos dos cidadãos frente às intrusões governamentais, a proporcionalidade eco-lógica (ou ecoproporcionalidade) deve proteger a natureza frente às intrusões da sociedade (incluindo o governo consumidor da natureza) (p.60). 
A ecoproporcionalidade, proposta como princípio de preservação do meio ambiente, não pode ser entendida senão a partir da compreensão da natureza jurídica difusa do bem ambiental, da indivisibilidade de seu objeto e da transindividualidade dos sujeitos de direitos relativos ao meio ambiente. Embora Gerd Winter (2013) refira-se precipuamente à adoção do princípio da ecoproporcionalidade nos atos legais, mediante a extensão da proporcionalidade referida à produção legislativa, notadamente nos países europeus não parece desarrazoado tomar-se como analogia a possibilidade de adoção de uma postura hermenêutica tendente a aplicar a ecoproporcionalidade, quando o Poder Judiciário se defronta com a judicialização de uma questão de violação do direito humano fundamental ao meio ambiente equilibrado, aproximando-se, talvez, nesse ponto, da resposta à pergunta formulada por Paulo Bonavides: "É o princípio da proporcionalidade um princípio de interpretação?" (BONAVIDES, 2003, p. 435). Pode-se afirmar, nessa ótica, que a consideração de princípios presentes no atual constitucionalismo representa um reforço à interpretação pretoriana, que deve se referenciar na natureza difusa do bem ambiental, de modo a afastar-se dos cânones positivistas pautados pelo individualismo.

O aumento da escassez de recursos naturais, diante do exponencial crescimento populacional, leva à circunstância de que, como contraparte dos direitos de que são titulares, os cidadãos também devem cumprir suas obrigações, pois a sociedade não pode ter a perspectiva perdulária de tempos passados de considerar infinitos os recursos que agora sabemos ser limitados, de sorte que "não é o mais o mero ambiente da humanidade a ser protegido mediante limites físicos às incursões humanas", mas, ao contrário, trata-se de "um recurso que deve ser preservado, a não ser que haja um bom motivo para consumi-lo (WINTER, 2013, p. 61).

Assim, "seria um grande passo à frente se pelo menos a consideração de alternativas se tornasse uma exigência geral" (WINTER, 2013, p. 62). A proposta é que sejam analisadas alternativas quando da realização de um empreendimento quanto ao seu escopo, de modo a considerar primordialmente o interesse difuso ao meio ambiente ecologicamente equilibrado, como direito humano fundamental garantido constitucionalmente, e que, de preferência, não se sujeite ao arbítrio subjetivo do empreendedor a escolha da melhor alternativa, mas que esta se prenda a critérios objetivos distanciados dos interesses dos agentes econômicos e mais próximos.

Desse modo, a cota de participação dos empreendedores na construção do meio ambiente ecologicamente equilibrado, ao abrir mão da predominância de seus interesses subjetivos pode equivaler, guardadas as proporções, às atitudes do consumidor preocupado com o consumo consciente, de modo a priorizar o uso de bens e serviços que resultem de um emprego mais racional dos recursos naturais não renováveis.

Esse mesmo princípio, aplicado na atividade judicante quando o Judiciário é instado a dirimir um conflito de competência ambiental, pode contribuir para que haja uma integração interpretativa que estabeleça a necessária adequação do interesse privado ao interesse coletivo e difuso em matéria ambiental.

Em sua obra "O princípio responsabilidade: ensaio de uma ética para a civilizaão tecnológica", Hans Jonas (2006) enfatiza que o poder causal é condição da responsabilização do agente, ou seja, que "os danos causados devem ser reparados, ainda que a causa não tenha sido um ato mau e suas consequências não tenham sido nem previstas nem desejadas". O autor afirma, ainda, que existe uma noção de responsabilidade que não se debruça sobre o fato consumado, mas que traz proposições quanto "à determinação do que se tem a fazer; uma noção em virtude da qual eu me sinto responsável, em primeiro lugar, não por minha conduta e suas consequências, mas pelo objeto que reivindica meu agir" (JONAS, 2010, p. 165-167).

Segundo Igor Suzano Machado, o princípio responsabilidade "vai de encontro à ética tradicional ao extrapolar (e muito) o espaço da cidade, o tempo presente e as relações com as pessoas próximas" e, portanto, "essa ética tradicional não daria conta da situação contemporânea pois não acompanharia uma mudança social fundamental, que fez a humanidade experimentar um comportamento humano capaz de feitos outrora inimagináveis" (2016, p. 254).

A amplificação das ameaças ao equilíbrio ambiental proporcionadas pelo avanço da técnica, exige a consideração da vida em termos globais e é essa a base da nova ética proposta por Jonas (2006). 


\section{Nas palavras de Machado (2016),}

antes da concretização de qualquer futuro profissional seu, por exemplo, cabe ao pai garantir que o filho esteja vivo até esse futuro. Antes da consolidação de qualquer aumento de sua riqueza, cabe ao governante garantir que a nação perdure de forma a poder usufruir dessa riqueza. Antes de qualquer ganho finito, deve vir o óbice à perda infinita, isto é, o óbice ao advento da impossibilidade de qualquer ganho. Esse é o vetor da ética da responsabilidade. Um extremo cuidado com o que se arrisca perante o que se espera obter, tendo como parâmetro não o bem absoluto que se pode atingir, porém sem o qual ainda é possível viver, mas sim o mal absoluto que sequer permite a vida (p. 257).

O princípio responsabilidade encontra-se diretamente ligado ao princípio da precaução, fundado na solidariedade com as futuras gerações, de modo que a imputação de responsabilidade civil ao gestor da empresa descumpridora das normas ambientais representa, no âmbito do novo constitucionalismo, uma parcela de contribuição para a primazia da manutenção e restauração do meio ambiente sobre os interesses subjetivos individuais, que perdem protagonismo no plano da hermenêutica emergente.

É preciso verificar, então, se a interpretação que se dá nos tribunais à norma constitucional de repartição de competências para o licenciamento ambiental aproxima-se dos novos parâmetros hermenêuticos relativos aos direitos difusos interindividuais nos limites da jurisdição aceitos no Estado Democrático de Direito, ou se foi ultrapassada a linha divisória entre os Poderes quando se admite que, a contrario sensu da norma vigente, por meio de um ativismo judicial a reboque do clamor público, o município possa, em princípio, legislar sobre licenciamento ambiental de empreendimento de mineração que traz impactos cuja magnitude recomenda a análise por corpo técnico qualificado, sabidamente inexistente na maioria dos municípios que sediam tais empreendimentos.

\section{A HERMENÊUTICA DAS DECISÕES}

A principal argumentação presente na decisão recorrida diz respeito à inconstitucionalidade da Lei Municipal de Santa Bárbara, que é inconstitucional por usurpar a competência legislativo-administrativa, ao determinar a nova submissão do empreendimento licenciado pelo órgão estadual a procedimentos típicos de licenciamento, em contrariedade ao disposto no artigo 13 da Lei Complementar 140, de acordo com a qual é possível aos municípios manifestarem-se ao órgão responsável pela licença ou autorização, de maneira não vinculante, respeitados os prazos e procedimentos do licenciamento ambiental.

De acordo com a decisão liminar, não cabe ao município exercer atos discricionários típicos de licenciamento quando há determinação legal de que determinados projetos, notadamente os de exploração mineral, devem ser licenciados por órgão estadual ou federal, pois "eventuais impactos ambientais decorrentes da instalação e operação do empreendimento submetido ao controle ambiental serão monitorados e sofrerão as devidas intervenções do órgão competente, não sendo permitida a superposição de competências entre os órgãos ambientais das três esferas administrativas" (BRASIL, 2017).

A decisão da presidente do STF, analisada neste artigo, parece corresponder à adoção do aparato cognitivo do paradigma hermenêutico emergente, no sentido de colocar o direito interindividual difuso ao meio ambiente equilibrado acima dos interesses subjetivos do empreendedor na obtenção da Certidão de Conformidade Ambiental, em contraposição ao velho paradigma anacrônico calcado na perspectiva civilista e individualista. Ao admitir, contudo, que o município pode legislar sobre matéria de competência constitucional claramente determinada, o julgado resvala no ativismo judicial para além da assim denominada interpretação criativa.

Ronald Dworkin, ao discorrer sobre o direito como integridade, afirma que a interpretação criativa busca a intenção, "não (pelo menos não necessariamente) porque pretenda descobrir os propósitos de qualquer pessoa ou grupo histórico específico, mas porque pretende impor um propósito ao texto, aos dados ou às tradições que está interpretando" ( 2014, p. 275).

Para ilustrar sua concepção da interpretação criativa a que se refere, em oposição à vertente positivistaformalista que ele execra, Dworkin (2014) criou a figura do romance em cadeia, analogia que coloca os juízes ao mesmo tempo como autores e críticos a tecer a continuidade de uma narrativa judicial. 
Em tal projeto, um grupo de romancistas escreve um romance em série; cada romancista da cadeia interpretativa interpreta os capítulos que recebeu para escrever um novo capítulo, que é então acrescentado ao que recebeu o romancista seguinte, e assim por diante. Cada um deve escrever seu capítulo de modo a criar da melhor maneira possível o romance em elaboração, e a complexidade dessa tarefa reproduz a complexidade de decidir um caso difícil de direito como integridade (DWORKIN, 2014, p. 276).

Esse gênero literário fictício serve para a demonstração de como, ao submeter o caso concreto à análise judicial, o juiz não se atém meramente ao direito positivado, mas, num movimento de integração, busca na comunidade de princípios entretecida, ao longo da elaboração desse romance, a solução para casos considerados difíceis, em que não se pode simplesmente invocar a letra fria da lei como fundamento.

Essa comunidade de princípios tem um fundamento axiológico, de tal maneira que não se pode mais afastar, diante da complexidade das relações jurídicas numa sociedade marcada pelo risco, o recurso a esse repositório de decisões políticas tomadas no passado pelos "romancistas" antecedentes, de modo que, "se essa comunidade de princípios endossa um princípio de preservação ambiental em uma dessas decisões políticas pretéritas das mais importantes - como sua Constituição - deve ser buscada a assimilação desse princípio numa concepção de justiça coerente e universalizável" (MACHADO, 2016, p. 262), mesmo à custa do liberalismo individualista.

Dworkin adverte, contudo, que a transferência de todo o poder político (que compreende o poder de elaborar as leis) aos juízes significaria a destruição do equilíbrio entre os poderes e da própria democracia, uma vez que "democracy supposes equality of political power, and if genuine political decisions are taken from the legislature and given to courts, then the political power of individual citizens, who elect legislators but not judges, is weakened, which is unfair"1 (DWORKIN, 2001, p. 27).

Nesse cenário, é interessante analisar a decisão da presidente do Supremo Tribunal Federal na mencionada Medida Cautelar na Suspensão de Tutela Antecipada 858 - MG, que acatou o pedido do município de Santa Bárbara, Minas Gerais, e tornou sem efeito a tutela antecipada concedida pelo desembargador relator do Tribunal de Justiça de Minas Gerais no Agravo de Instrumento n. 0317791-76.2017.8.13.0000, consistente na determinação da emissão da Certidão de Conformidade Ambiental para fins de licenciamento ambiental, "independentemente de qualquer análise técnica ou solicitação de dados ou estudos complementares" (BRASIL, 2017), ou seja, se o julgado encerra um ativismo judicial, por ignorar as lindes do modelo de repartição de competências e admitir, em tese, a possibilidade de o município legislar para além das atribuições legislativas que Ihes confere o texto constitucional, ou se, ao contrário, foi uma decisão que acessou a comunidade de princípios a que se refere Dworkin como fonte privilegiada, e realizou, assim, o Direito como integridade.

A Certidão de Conformidade Ambiental, exigida como requisito dentro do processo de licenciamento ambiental de um projeto de captação de dois milhões de litros de água por hora do Rio Conceição, com a finalidade de alimentar um mineroduto com origem no município de Mariana, havia sido condicionada ao cumprimento de exigências relacionadas a análises técnicas e de estudos específicos.

A fundamentação da medida concessiva da liminar no Tribunal pelo Tribunal a quo foi no sentido de que

Não cabe ao município exigir a realização de estudo ambiental para emissão da certidão prevista no artigo 10, $\S 1$ 1, da Resolução CONAMA 237, de 1997, visto que o licenciamento é de competência do órgão ambiental estadual, devendo a municipalidade apenas manifestar-se sobre a observância pelo empreendimento da lei de uso e ocupação do solo. Eventuais impactos decorrentes da instalação e operação do empreendimento submetido ao controle ambiental serão monitorados e sofrerão as devidas intervenções do órgão competente, não sendo permitida a superposição de competências entre os órgãos ambientais das três esferas administrativas (BRASIL, 2017).

\footnotetext{
${ }^{1}$ A democracia pressupõe equilíbrio do poder político, e se as decisões genuinamente políticas são subtraídas dos legisladores e atribuídas aos tribunais, então o poder político dos cidadãos, que elegem políticos e não juízes, estaria enfraquecido, o que não é justo" (tradução nossa).
} 


\section{Debate}

Ao acolher o pedido de suspensão da medida liminar que havia determinado a emissão da certidão, a presidente do STF deixou claro que não foi analisado o mérito na ação de origem e nem se discutiu, por incabível naquela via processual, a constitucionalidade do Decreto Municipal no 2.438/2013, com ênfase no exame "da presença dos aspectos relacionados à potencialidade lesiva do ato decisório em face dos interesses públicos relevantes legalmente assegurados" (BRASIL, 2017).

Sem, portanto, abordar o mérito do conteúdo normativo do decreto municipal, embora não se possa negar que a decisão em qualquer sentido tangencia o fundo do direito, a ministra assevera que

a suspensão de decisão pela qual se confere ao ente municipal a atribuição de competência do chefe do Poder Executivo municipal determinante para a continuidade do procedimento de licenciamento de atividade mineradora, é medida de precaução, necessária para se evitar que, antes da devida avaliação técnica de riscos, sejam praticados atos pela Interessada, que podem - como se afirma - agravar a situação de risco a que estaria exposta toda a coletividade (BRASIL, 2017).

Ao considerar a existência de risco inverso, ou seja, no sentido da precariedade da obra sem o acompanhamento técnico do município, a decisão na Medida Cautelar parece firmar-se na presunção de que o órgão ambiental estadual competente é omisso ou hipossuficiente em seu dever de realizar o acompanhamento técnico que lhe é atribuído por força de lei para a concessão e renovação da Licença de Operação. Seria, então, necessária a suplementação, por parte do município, nesse quesito típico do processo de licenciamento ambiental, de procedimentos que não se encontram previstos em lei?

Parece trazer muitas dúvidas o fato de que a emissão da certidão de conformidade ambiental, objeto da controvérsia da Medida Cautelar em questão, tem caráter vinculante, sem qualquer margem de discricionariedade. Não se pode condicionar sua expedição a nenhuma exigência, pois se trata de declaração que deve responder simplesmente: $O$ empreendimento está conforme ou desconforme ao Plano Diretor? Se não há conformidade, a respectiva declaração deve trazer as razões dessa desconformidade, posto que de ato típico de licenciamento obviamente não se trata na espécie, mas de ato administrativo vinculado, ou seja, que deve ser praticado independentemente do cumprimento de exigências.

\section{CONSIDERAÇÕES FINAIS}

Conforme se aproxime do mérito ou dele se distancie é que se terá a resposta ao questionamento acerca do acerto da decisão do Supremo Tribunal Federal ora em análise. Se o Decreto Municipal condiciona a emissão de certidão ao cumprimentos de requisitos outros que não se atenham a sua conformidade ou desconformidade do Plano Diretor, parece evidente que sua mens legis é no sentido de que a emissão da aludida certidão deixa de ter caráter vinculante para se submeter ao escrutínio discricionário do administrador municipal, que não é órgão licenciador de empreendimentos minerários.

No plano da repartição de competências administrativas e legislativas delineada pela Constituição da República, o município, como locus da cidadania, representa um importante papel no que se refere ao denominado interesse local. É no espaço geográfico e territorial do município que se desenvolve a vida produtiva, o que pode levar a uma interpretação extensiva dessa expressão, de modo a atribuir-se ao ente municipal capacidades operacionais e técnicas de que ele não está habilitado a exercer.

É sobre os limites do "interesse local" que se deve refletir quando esse argumento é invocado para fundamentar decisões judiciais, como no caso de atribuir-se ao município a competência legislativa do licenciamento de empreendimentos de alto impacto ambiental, como no caso da mineração.

Se, por um lado, é inegável o papel do município na proteção do meio ambiente, nos termos do inciso VI do artigo 24 da Constituição da República de 1988, por outro há vedação constitucional à edição de norma municipal destinada a suplementar a legislação federal e a estadual, porquanto consta do inciso II do artigo 30 da CF/88 a expressão "no que couber". Evidentemente não cabe ao município legislar, por exemplo, sobre jazidas, minas e outros recursos naturais (artigo 22, XII, CF) e, por extensão, é-lhe vedado, também, legislar sobre licenciamento ambiental de empreendimentos de mineração.

Não restam dúvidas de que, na questão da repartição das competências em matéria legislativa, sob o ponto de vista da ecoproporcionalidade, os interesses difusos relacionados ao bem ambiental encontram no município o local ideal para se decidir acerca da conveniência de determinado empreendimento causador de 
grande impacto ambiental. Não é possível, contudo, diante da adoção da hermenêutica dos princípios, conferir à letra da lei interpretação extensiva em matéria de repartição de competências legislativas em matéria ambiental.

Em uma primeira abordagem, a percepção é a de que o julgado traz elementos robustos a reforçar a adoção de um paradigma hermenêutico que tenha em perspectiva a ecoproporcionalidade, no sentido de se sopesar os interesses privados com o direito difuso ao meio ambiente ecologicamente, mas para que se chegue a essa conclusão deve-se abstrair da apreciação do mérito num ponto determinante: a competência legislativa dentro do sistema de repartição constitucional.

À primeira vista, a decisão do STF prestigiou o princípio da precaução, segundo o qual, sendo desconhecidos os riscos de um empreendimento, a melhor opção é deixar de aprovar sua execução até que seja comprovada a ausência de riscos consideráveis ao meio ambiente. Ao esquivar-se do mérito (analisar a competência legislativa do município em matéria de licenciamento ambiental), porém, o julgado parece haver avançado no terreno do ativismo judicial e chancelado a usurpação de competência legislativa determinada constitucionalmente.

Embora o mérito não tenha sido abordado na decisão do STF, o que importa delimitar aqui é o grau de ingerência que o Poder Judiciário pode exercer sobre a seara legislativa para além dos limites de controle da legalidade e da constitucionalidade dos atos da administração municipal.

Parece claro que, não havendo previsão legal de que cabe ao município praticar atos legislativos que desbordam a competência que Ihe foi constitucionalmente atribuída, a decisão judicial que referenda a existência de legislação típica de licenciamento ambiental é puro ativismo judicial, muito embora tenha se pautado pela hermenêutica fundada na comunidade de princípios, apesar de ter sido fundamentada na necessidade de se aplicar a ecoproporcionalidade na aprovação ou recusa de um empreendimento.

Desse modo, é louvável o movimento da hermenêutica que se funda na comunidade de princípios para chegar a melhor conclusão, mas há que se precaver contra a tentação legiferante e o ativismo judicial que se abrigam em meio a essa nova roupagem interpretativa, sob pena de se consentir na conformação de um populismo ambiental que não deve ter a chancela do Poder Judiciário.

\section{REFERÊNCIAS}

BONAVIDES, Paulo. Curso de Direito Constitucional. 13. ed. São Paulo: Ed. Malheiros, 2003.

BRASIL. 2017. Disponível em: <http://www.stf.jus.br/portal/jurisprudencia/listarJurisprudencia.asp?s1=\%28\%28MEDIDA+CAUTELAR+NA+SUSPENS\%C3O+DE+TUTELA+ANTECIPADA+\%3A+MC+STA+858+MG+\%2D+MINAS+GERAIS\%29\%29+E+S\%2EPRES\%2E\&base=basePresidencia\&url=http://tinyurl.com/y79a3r74>. Acesso em: 29 abr. 2018.

CASTRO, José N. Direito municipal positivo. 6. ed. Belo Horizonte: Del Rey, 2010.

COSTA, Beatriz S.; REIS, Émillien. V. B.; OLIVEIRA, Márcio Luiz. Fundamentos filosóficos e constitucionais do Direito Ambiental. 2. ed. Rio de Janeiro: Lumen Juris, 2016.

COSTA, Beatriz S. Meio ambiente como direito à vida - Brasil, Portugal e Espanha. 2. ed. Rio de Janeiro: Lumen Juris, 2013. DEUS, Tereza Cristina. Tutela da flora em face do Direito Ambiental brasileiro. São Paulo: Juarez de Oliveira, 2003.

DWORKIN, Ronald. A matter of principle. New York: Oxford University Press, 2001.

. A justiça de toga. 3. ed. São Paulo: Martins Fontes, 2010.

. O império do Direito. 3. ed. São Paulo: Martins Fontes, 2014.

JONAS, Hans. O princípio responsabilidade: ensaio de uma ética para a civilização tecnológica. Rio de Janeiro: Ed. PUC, 2006.

MACHADO, Igor Suzano. Comunidade de princípios e princípio responsabilidade: o juiz Hércules confuso diante de uma natureza ameaçada. Revista Veredas do Direito, Belo Horizonte, v. 13, n. 27, p. 243-265, set./dez. 2016. Disponível em: <http:// www.domhelder.edu.br/revista/index.php/veredas/article/view/860>. Acesso em 28 abr. 2018.

SANTOS, Boaventura de Sousa. Um discurso sobre as ciências. 7. ed. São Paulo: Cortez Editora, 2010.

STRECK, Lenio Luiz. Verdade e consenso. 5. ed. São Paulo: Saraiva, 2014.

. Hermenêutica jurídica em crise: uma exploração hermenêutica da construção do Direito. 11. ed. São Paulo: Livraria do Advogado, 2017.

WINTER, Gerd. Proporcionalidade "Eco-Lógica": um princípio jurídico emergente para a natureza? Veredas do Direito, Belo Horizonte, v. 10, n. 20, p. 55-78, jul./dez. 2013. 